\title{
Aspects of Human Security, Social Justice and Sustainable Development in Africa: Nigeria as a Case Study
}

\author{
Dhikru Adewale Yagboyaju, PhD \\ Department of Political Science, University of Ibadan, Nigeria. \\ E-mail: aswaj2003@yahoo.com
}

Received: Jul. 21, 2019 Accepted: Aug. 20, 2019 Online published: Sep. 29, 2019

doi:10.5296/jpag.v9i3.15536 URL: https://doi.org/10.5296/jpag.v9i3.15536

\begin{abstract}
This paper analyzes the relationships between selected aspects of human security-poverty and health security, social justice and sustainable development in Nigeria, representing the African continent. Human security, an emerging paradigm for understanding global vulnerabilities, is widely defined as consisting of seven key areas. However, the aspects of poverty and health security are selected for this study because of the overlapping effects on all the other aspects. Data for the conceptual and theoretical section of the paper are drawn from secondary sources and complimented by data from primary sources. These include events analyses by the author and content analyses of documents such as United Nations (UN) Human Development Index (HDI), Legatum Prosperity Index and Mo Ibrahim Index of African Governance (IIAG) for a selected period. Research methodology is case study based.

The paper's main finding centres on the levels of poverty and threats to health security that have confronted majority of ordinary Nigerians in the past two decades despite the country's huge material endowments. In the light of this, the focus of knowledge in the country's immediate and distant future should be human security and not state-centric security.
\end{abstract}

Keywords: sustainable development, human security, social justice, governance, Nigeria

\section{Introduction}

Despite the growing acceptance of democratic governance processes and the promise of sustainable development, since the early 1990s, the continent of Africa is, almost three decades after, still grappling with multiple crises. Among these, security challenges stand out for obvious reasons. Civil wars in Liberia and Sierra Leone; post-election violence in Kenya between 2007 and 2008;presidential standoff in Cote d'Ivoire in 2010-2011; coups d'etat in 
Mali and Guinea Bissau in 2012; upheavals in North Africa (Tunisia, Egypt and Libya) since 2011, and the associated migratory flows, as well as the uprising in the Sudan in 2019, coupled with violent extremism and terrorism across the continent, reinforce the value of taking a hard look at underlying social, economic and political conditions that have the potential to trigger change for the worse (see Lewis 2011:1-17; Aning 2016:1-15).

Nigeria is Africa's most populous country, with a projected population of 159.4 million in 2010 (a decade ago), and among its most diverse, with more than 250 distinct ethnic and linguistic groups. Nigeria is one of the ten most populous countries in the world. Its population represents one-quarter of sub-Saharan Africa and one-fifth of the black race. The country has about the sixth largest deposit of gas in the world and is the eighth largest Organization of Petroleum Exporting Countries (OPEC) oil producer (see Jega 2010:1-14; Akande and Roberts 2010:1-29). These factors potentially place Nigeria in a leadership position, not only in the West African sub-region but in the whole of the continent of Africa. Sobriquets like Giant of Africa, The Elephant and The Hope of Black Race were already in use in reference to the country at political independence in 1960. Yet, Nigeria was until recently one of Africa's most chronically unstable and conflict-ridden countries.

Weak economic and political structures, ineffective institutions and processes, and poor governance, characterized by quarrelsome, inept and corrupt public officers have combined to undermine the capacity of the country, especially in ensuring and sustaining development for the good of all. Why has Nigeria remained a potentially great country without significantly realizing its potential for social and economic progress? What are the key factors that have driven Nigeria's development aspirations over the years and what impact have they made on human welfare starting, in particular, from security? What lessons can be drawn from the trajectory of Nigeria's development journey in addressing the country's current development challenges? What are the correlations between these and concentration on state-centric security in Nigeria, like many parts of Africa?

The aim of the paper is to examine the status and challenges of sustainable development in Africa, using Nigeria as the point of contact. The objectives are in essence to:

- Analyze foundational factors for these challenges.

- Sketch out some potential scenarios, with information drawn from UN's HDI, Legatum Prosperity Index and Mo Ibrahim's IIAG. Both the aim and objectives are derived from the research questions that the paper has set for itself. The rest of the paper is divided into six main sections. They are namely: conceptual/theoretical issues and literature review; elements of human security and effects on development; nexus between human security, social justice and sustainable development; analysis of selected reports; conclusion and; recommendations.

\section{Conceptual/Theoretical Issues and Literature Review}

Development as a concept does not lend itself to a universal or ultimate definition (see Yagboyaju 2017: 45-74). Quite often, development is viewed from the perspective of economic growth and sometimes wrongly interchangeably applied. Both are interrelated, but there exists some distinguishing elements. Growth emphasizes numbers, including "tangible, 
quantitative, and macro economic indicators such as increase in income per capita, increase in output and gross domestic product (GDP), increase in external reserves, increased trade revenue, and balance of payments surplus" (Oluwa2012:16). On the other hand development, as espoused in the UN documents on Millennium Development Goals (MDGs) and Sustainable Development Goals (SDGs), emphasizes different issues. In these documents, the concept of development emphasizes qualitative improvement in the living conditions of the citizenry. It focuses on the accessibility by ordinary citizens to basic necessities and good things of life such as food, drinkable water, clothing, shelter, basic health care, public sanitation, education, and job opportunities among others.

The UN Millennium Summit of 2000 came up with the following development goals:

i. Eradication of extreme poverty and hunger;

ii. universal primary education;

iii. promotion of gender equality and empowerment of women;

iv. reduction of child mortality;

v. improvement of maternal health;

vi. combating HIV/AIDS, malaria and other (endemic) diseases;

vii. ensuring environmental sustainability and;

viii. designing of a global partnership for development (UN 2000).

A timeline of 15years for a review was set and this, in 2015, became the basis for the enlarged SDGs. Eighteen quantifiable targets, measured by 48 indicators were set. Among these key indicators, consolidation of electoral democracy stands out. As Olopoenia (1998), Roberts (1999), Simbine (2000), Simbine and Oladeji (2010) and Yagboyaju (2017) advanced, while economic growth is a fundamental component of development, the contemporary understanding of the phenomenon of development emphasizes some key attributes that are not necessarily economic nor physical in nature. These include social justice, political inclusiveness and the right to participate in public affairs in general.

An important observation is that all the items on the MDGs and SDGs are related to intangible feel good issues, while more than $50 \%$ of these concern society's most vulnerable groups - females and children. Also of importance is the critical factor of governance in actualizing development aspirations and attaining goals. As Rogers and Hall (2003:2) put it, governance involves the manner in which "allocative and regulatory mechanisms are exercised in the management of resources (natural, economic and social) for the good of the citizenry and broadly embraces the formal and informal institutions by which authority is exercised". Poor governance leads to "increased political and social risks, institutional failure and rigidity and a deterioration in the capacity to cope with shared problems". Effective or good governance is often adopted as a synonym for democracy in contemporary literature, especially because democracy "disallows policies from being arbitrarily made and hence assures laid-down rules and a high degree of continuity for social and political order" 
(Simbine 2000:14).

The concepts of human security and social justice are mutually reinforcing with those of development and governance. There is hardly any consensus on the meaning of human security, owing in part to the strategic appropriation of the term "security" by diverse actors. Thus, according to Paris (2001:87), the concept of human security has been criticized for lacking a precise meaning and for the "definitional elasticity of its formulations". Even with the proposition by the United Nations Development Programme (UNDP), the inclusion of general factors such as social, economic, cultural, and psychological wellbeing to the main component of physical security makes it practically impossible for policymakers to proffer specific priorities and solutions to specific issues. Nonetheless, recent formulations have, according to Aning (2016:7), sought to curtail the expansive concept by narrowing it to the "essential indicators of wellbeing-poverty, health, education,political freedom, and democracy". In the specific context of Africa, a practical expression of human insecurity and the attendant social injustices result to state failure to protect their own citizens and, in worse case scenarios, result in "collapse leading to such states becoming both the incubators and vectors of insecurity" (Aning, p.7). The paper returns to a detailed analysis of this in a subsequent section.

Social justice, according to Miller (1991:371-391), has been applied differently by different people. However, he disagrees with the notion that the concept is meaningless and vague. Jost and Kay (cited in Aning 2016:9) have offered a definition which seems relatively well accepted. They define social justice as:

A state of affairs... in which benefits and burdens in society are dispensed in accordance with some allocative principle (or set of principles); procedures, norms and rules that govern political and other forms of decision-making preserve the basic rights, liberties and entitlements of individuals and groups and; human beings (and perhaps other species) are treated with dignity and respect not only by authorities but also by other relevant social actors, including other citizens.

Three aspects of social justice, namely: distributive, procedural and interactional dynamics are clear in the above definition. While distributive and procedural justice relate more to the state in this context, interactional justice typifies the relationship between employees on the one hand, and an employer and employees on the other. Three principles, namely: equality, proportionality and fairness are the basis for distributive justice. For example, equal work should provide individuals with equal outcomes in terms of goods acquired or the ability to acquire goods. Thus, distributive justice is absent when equal work does not produce equal outcomes or when an individual or a group acquires a disproportionate amount of goods. Procedural justice is concerned with making and implementing decisions according to fair processes. For example, a loser in a keenly contested election accepts the outcome which he does not like with a feeling of assurance in the process. The combination of the principles above with the principles of consistency, impartiality and neutrality as well as transparency are the building blocks for interactional justice.

There is a correlation between the concept of social justice and the phenomenon of social 
closure. Following the pioneering work of Max Weber (b. 1864 - d. 1920), Parkin (1982) utilized the concept of social closure to explain a process in which collectivities seek to maximize rewards by restricting access to resources and opportunities to a limited circle of eligibles. Socio-economic and political factors ranging from race, religion and sex, to social and economic status are often applied in such restrictions.

Whether as in Ghana where, in 2015, a video expose by Anas Aremeyao Anas led to the suspension of seven high court judges, or Nigeria where, in 2018/2019, the Chief Justice voluntarily retired in connection to non-compliance with assets declaration regulations, or other forms of procedural abuses around Africa, the issue of justice is a serious matter (www.telegraph.co.uk/news/worldnews/africanandindianocean/ghana;

www.jc.gov.ng/press-release).The crux of the matter is that any act which undermines justice erodes trust in the rule of law, and by extension security and freedom from fear. It breeds inclinations for recourse to self-help, which is a recipe for anarchy and breakdown of law and order.

\section{Elements of Human Security and Effects on Development}

Two of the elements of human security - poverty and health security, which are some of the common human security indicators in leading reports around the world, are discussed in this section. Existing fears and concerns regarding the links between poverty and forced migration in Nigeria are discussed as a sub-theme.

Many documentary evidences (see Falola2018:283-305; Kumuyi and Adesanya 2010:895-924; Roberts et al 2003: 415-467; The Punch 2010: pp. 2 and 7; UNDP 2009; Bello and Roslan 2010:7-17) support the claims on poverty being a major problem in Nigeria. As in other parts of Africa where, in particular, since after World War II poverty became a topical issue, debates and policies on poverty in Nigeria have been on for long. These became intensified in the 1990s when the issue of human security appeared at the forefront of international security discourse.In 1999, the International Monetary Fund (IMF) and World Bank adopted the Poverty Reduction Strategy Paper (PRSP), followed by the UN Millennium Summit of 2000 at which the MDGs were adopted to signify the trajectory towards human security. This has systematically been followed up by the SDGs in 2015. Of the eight MDGs, eradicating extreme poverty and hunger is the first, and this is the same in the expanded SDGs. Indeed, according to Esho and Sonoyama (cited in Aning 2016:13), pover reduction is "the most important issue confronting the international community today".

While extreme poverty is measured according to the SDGs as people living on less than \$2 a day, the interconnectedness of the 17 SDGs point to something more critical. It is noted that poverty is:

... more than the lack of income and resources to ensure a sustainable livelihood. Its manifestations include hunger and malnutrition, limited access to education and other basic services, social discrimination and exclusion as well as the lack of participation in decision-making... Economic growth must be inclusive to provide sustainable jobs and promote equality (www.sustainabledevelopment.un.org). 
This recognition is critical as it enables specific policies to address issues of exclusion that have been cited in a preceding section of this paper as indicators of social injustice. In Nigeria, Ajakaiye and Olomola (2003) have emphasized that poverty transcends the economic realm. It has been described as a multidimensional phenomenon covering all sectors of the economy-agriculture, education, technology, housing, politics and social sectors. This and other salient aspects of the poverty profile in Nigeria are covered in details in the subsequent section on the analyses of selected reports.

Health security has been described as particularly susceptible within the framework of human security. This, according to Periago (cited in Aning 2016:13), is in view of its "close correlation with other indicators". Common threats include "scarce water and sanitation systems, disease pandemics, physical and emotional violence, inadequate access to maternal and child healthcare, and precarious roads and transportation systems" (Aning, p. 13). Various components of human security that are also closely linked to the determinants of health include: food security, environmental security, economic security, personal security and community security. Captured under these headings are the issues of sufficiency of nutrition; pollution of air, water and sanitation; employment opportunities; protection from threats of war, crime, violence, rape, child abuse and drug abuse; and promotion of healthy lifestyles and strong social systems as well as political security, including human dignity and rights protection.

Health security is of critical importance in Africa not only because of the existing vulnerabilities, but also because of the structural challenges confronting the continent. According to Aning (p. 14), this is magnified "particularly in border communities", where border porosity is a matter of serious concern. The Ebola pandemic which resulted in a death toll of tens of thousand, and spread across Liberia, Sierra Leone, Guinea and other countries is an unavoidable reminder of the human and material costs of health emergencies. In Nigeria, Dr. Ameyo Stella Adadevoh died on 19 August 2014 after her contact, during the treatment of the first reported case of an ebola patient, in July 2014 (see www.drasatrust.org). This further demonstrates the close interlinkages between health security and other indicators of human security, and in effect societal development.

\section{Linkages Between Human Security, Social Justice and Societal Development}

The scope of human security has been expanded from the initial issue of human rights, to encompass rule of law and development. Thus, it has become the responsibility of governments in Africa to create necessary structures, institutions and human capital to develop these areas of human security. But such efforts can only translate into social equity and justice when, according to Taylor (2013:12-13), they are guided by "procedures, rules and principles that are adhered to by all irrespective of social, economic and political status". Impliedly, application of such procedures, rules and principles are not discriminatorily based on ethnic, racial, religious or political affiliations. Development projects, including health and educational institutions, roads and drinkable water, are extended to various parts of the country on clear formulae that seek to ensure relatively equal distribution of state resources.

The relationship between human security and social justice is not spontaneous, neither is it 
impulsive while human security is widely desired, it requires deliberate and purposive policies targeted at equity in order to produce social justice. For example, despite the economic growth in Nigeria and various parts of Africa, at different points in time, a critical analysis of the level of human development reveals the disjuncture between economic growth as an indication of development and the conditions of the ordinary citizens (see Erinosho 2010:59-92; Yagboyaju 2016:99-132). Such examples of uneven development reinforce the notion of social injustice in many parts of the continent of Africa.

The adoption of specific policies targeted at addressing issues of social justice, especially in connection to the reduction of extreme poverty is, therefore, commendable. For example, in Nigeria, there have been policies and programmes for broad as well as specific areas in recent times. In broad terms, there have been National Economic Empowerment and Development Strategy (NEEDS), built on the preparation of the nation's Interim Poverty Reduction Strategy Paper (IPRSP), National Poverty Eradication Programme (NAPEP), and Economic Recovery and Growth Plan (ERGP), all of these coming since the 1999 commencement of the country's Fourth Republic. Programmes for specific areas include Niger Delta Development Commission (NDDC) and North East Development Commission targeted at addressing issues of extreme poverty caused by environmental degradation and pollution from oil exploration activities, and war devastation by the activities of insurgents and Boko Haram terrorists respectively.

This commendation is, not out of place because of the extreme conditions of poverty in these areas, knowing well that real societal development cannot be achieved unless a social justice lens is incorporated in human security. It is, therefore, shocking that there have been instances of mismanagement and diversion of funds from such programmes that are meant for the downtrodden (see www.premiumtimesng.com; www.punchng.com; www.saharareporters. com).

\section{Analysis of Selected Reports}

Poverty and health security, the key elements isolated in a preceding section of the paper in view of their linkages with every other element of human security and sustainable development are linked to prosperity. In this context, prosperity denotes favourable circumstances to thrive, flourish and achieve self-actualization even if there are challenges.In analyzing the probability of achieving prosperity by the greatest number of Nigerians and the effects on human security as well as national security, the Annual Prosperity Index (API) of the London-based Legatum Institute, Ibrahim Index of African Governance (IIAG) and the United Nations Development Programme (UNDP) Human Development Index (HDI), covering 2008-2017, are content-analyzed.

There has been concern on the issue of poverty in Nigeria since the 1980s with the gradual deterioration in the welfare of the people. According to the then Federal Office of Statistics (now National Bureau of Statistics), poverty incidence grew "from 27.2\% in 1980 to $65.6 \%$ in 1996", showing an annual average increase of $8.83 \%$ over a 16 -year period. However, between 1996 and 2004, this proportion declined by an annual average of " $2.1 \%$ to $54.4 \%$ " (cited in Kumuyi and Adesanya 2010:902). Despite this seeming improvement between 1996 
and 2004, the proportion of Nigerians who are poor, two decades into the $21^{\text {st }}$ century, is twice the proportion in 1980. This figure is about 25\% higher than the Sub-Saharan Africa (SSA) average (see Adamolekun 2016:35pp).

Other salient aspects of the poverty profile in Nigeria include:

- Poverty incidence in the country is relatively higher among rural households than their urban counterparts. Poverty incidence grew unsteadily from $28.3 \%$ in 1980 to $63.3 \%$ in 2004 among rural households, and from $17.2 \%$ to $43.2 \%$ among urban households during the same period (see National Bureau of Statistics - NBS 2005:22-24; Bello and Roslan 2010:7-17). Thus, poverty grew at a faster rate in the rural areas.

- Poverty varies between female - and male - headed households. As the defunct Federal Office of Statistics (FOS) survey data shows, poverty incidence in male-headed households was " $66.5 \%$ in 1996 , compared to $58.5 \%$ in female headed households". The figures for "male-headed households in 1992, 1985 and 1980 were $43.1 \%, 47.3 \%$ and $29.2 \%$ respectively as against $39.9 \%, 38.6 \%$ and $28 \%$ respectively in the case of female-headed households" (Kumuyi and Adesanya 2010:902).

Bringing to mind the assertion by Ajakaiye and Olomola (cited in Kumuyi and Adesanya 2010) that poverty in Nigeria "transcends the economic realm" the data above have serious multidimensional implications. These cover critical sectors such as agriculture, education, technology, housing, politics and social sectors. For example, for Nigeria with a huge population of rural dwellers and, at the same time, one with a society still largely dependent on family values of being one's brother's keeper and communal life, the huge data on poverty in rural households as well as male - and female - headed households should generate concern. A troubled rural life and devastation of family values have serious implications on the country's entire social fabric and, by extension, national security.

The first five out of the six tables below provide data from UN HDI, Legatum Prosperity Index and IIAG. They cover all aspects of human security and social justice but, in view of the focus of this paper on aspects of human security, emphasis is on poverty and health security in the analyses.

Table 1. Criteria for Prosperity Assessment

\begin{tabular}{|c|c|c|}
\hline $\begin{array}{l}\text { Ibrahim Index of African Governance } \\
\text { (IIAG) }\end{array}$ & $\begin{array}{l}\text { Legatum Institute's } \\
\text { Prosperity Report }\end{array}$ & $\begin{array}{l}\text { Human } \\
\text { Development } \\
\text { Index (HDI) }\end{array}$ \\
\hline $\begin{array}{l}\text { 1. Sustainable } \\
\text { Opportunity (Infrastructure, Public } \\
\text { Management, Business } \\
\text { Environment, Rural Sector). }\end{array}$ & $\begin{array}{l}\text { Economy } \\
\text { (Macro-Economic } \\
\text { policies, economic } \\
\text { satisfaction and } \\
\text { expectations, } \\
\text { foundations for growth, } \\
\text { and financial sector } \\
\text { efficiency). }\end{array}$ & $\begin{array}{l}\text { GDP per Capita } \\
\text { (Income) }\end{array}$ \\
\hline $\begin{array}{l}\text { 2. Safety and Rule of Law (Personal } \\
\text { Safety, National } \quad \text { Security, }\end{array}$ & $\begin{array}{l}\text { Entrepreneurship and } \\
\text { Opportunity }\end{array}$ & $\begin{array}{l}\text { Health-longevity } \\
\text { (life expectancy at }\end{array}$ \\
\hline
\end{tabular}


Accountability, Rule of Law)

(entrepreneurial

environment, promotion

of innovative activity, and evenness of opportunity).

3. Participation and Human Rights (Participation, rights, gender)

Governance (effective and accountable government, fair elections and political participation, rule of law)

4. Human Development (Education, Health, Welfare).

Education (access to education, quality of education, and human capital)

\begin{tabular}{|c|c|}
\hline - & $\begin{array}{l}\text { education, and human } \\
\text { capital) }\end{array}$ \\
\hline & $\begin{array}{lr}\text { 5. Health (basic } & \text { health } \\
\text { outcomes, } & \text { health } \\
\text { infrastructure, } & \text { and } \\
\text { preventive care). } & \end{array}$ \\
\hline & $\begin{array}{l}\text { 6. Safety and Security } \\
\text { (national security and } \\
\text { personal security) }\end{array}$ \\
\hline & 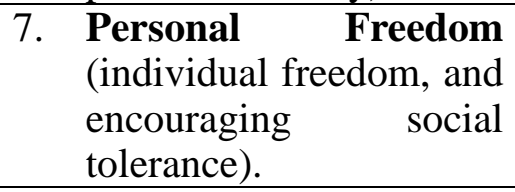 \\
\hline & $\begin{array}{l}\text { 8. Social Capital (social } \\
\text { cohesion } \\
\text { engagement, and } \\
\text { community and family } \\
\text { networks). }\end{array}$ \\
\hline
\end{tabular}

Source: Author (based on information available on the websites of Mo Ibrahim Foundation, Legatum Institute and UNDP - 29/06/2019 @ 06.18hrs).

Table 2. Nigeria's Prosperity Assessment, 2008 - 2017.

\begin{tabular}{|c|c|c|}
\hline Year & $\begin{array}{l}\text { Legatum Prosperity } \quad \text { Index } \\
\text { (Ranking of Countries }\end{array}$ & $\begin{array}{l}\text { Ibrahim Index of African Governance } \\
\text { (Ranking and Score/100) }\end{array}$ \\
\hline 2008 & $95^{\text {th }}$ out of 104 & $39^{\text {th }}$ out of $48 ; 44.9$ \\
\hline 2009 & $98^{\text {th }}$ out of 104 & $38^{\text {th }}$ out of $53 ; 50.3$ \\
\hline 2010 & $106^{\text {th }}$ out of 110 & $40^{\text {th }}$ out of $48 ; 43.0$ \\
\hline 2011 & $104^{\text {th }}$ out of 110 & $41^{\text {st }}$ out of $53 ; 43.4$ \\
\hline 2012 & $123^{\text {rd }}$ out of 142 & $43^{\text {rd }}$ out of $52 ; 44.9$ \\
\hline 2013 & $123^{\text {rd }}$ out of 142 & $41^{\text {st }}$ out of $52 ; 43.4$ \\
\hline 2014 & $125^{\text {th }}$ out of 142 & $37^{\text {th }}$ out of $52 ; 45.8$ \\
\hline 2015 & $125^{\text {th }}$ out of 142 & $36^{\text {th }}$ out of $54 ; 44$ \\
\hline 2016 & $136^{\text {th }}$ out of 142 & $35^{\text {th }}$ out of $54 ; 48.1$ \\
\hline 2017 & $132^{\text {nd }}$ out of 142 & $33^{\text {rd }}$ out of $54 ; 47.9$ \\
\hline
\end{tabular}




\section{Macrothink}

Journal of Public Administration and Governance

ISSN 2161-7104

2019, Vol. 9, No. 3

Source: Author (based on information available on the website of Legatum Institute and Mo Ibrahim Foundation - accessed on 29/06/2019).

Table 3. Nigeria's Human Development Index and Ranking - Selected Years between 1990 and 2017

\begin{tabular}{|l|c|c|}
\hline Year & HDI & Ranking \\
\hline 1990 & 0.43 & $112 / 134$ \\
\hline 1995 & 0.45 & $118 / 144$ \\
\hline 1998 & 0.44 & $151 / 174$ \\
\hline 2002 & 0.46 & $125 / 151$ \\
\hline 2004 & 0.45 & $159 / 177$ \\
\hline 2010 & 0.493 & $158 / 177$ \\
\hline 2011 & 0.499 & $156 / 187$ \\
\hline 2012 & 0.505 & $153 / 186$ \\
\hline 2013 & 0.511 & $153 / 187$ \\
\hline 2014 & 0.514 & $145 / 187$ \\
\hline 2015 & 0.514 & $152 / 188$ \\
\hline 2016 & 0.532 & $152 / 188$ \\
\hline 2017 & 0.532 & $157 / 189$ \\
\hline
\end{tabular}

Source: Author (based on information available on the website of the UNDP).

*The bounce from GDP rebasing in 2014 accounts for the significant improvement in the scores since 2010 - the impact of GDP rebase was used to re-calculate the HDI up to 2010 on UNDP website - accessed on 29/06/2019). (The scores are out of a total of 1.0).

Table 4. Nigeria's Ranking in Ibrahim Index of African Governance (IIAG)

\begin{tabular}{|c|c|c|}
\hline CRITERIA & 2017 (Ranking and Score) & $\begin{array}{l}2008-2017 \\
\text { Average Sore }\end{array}$ \\
\hline $\begin{array}{llr}\text { 1. } & \text { Sustainable } & \text { Economic } \\
\text { Opportunity (Infrastructure; } & \text { Public Management; Business } \\
\text { Environment; Rural Sector) }\end{array}$ & $34^{\text {th }}(39.5 \%)$ & $34.1 \%$ \\
\hline $\begin{array}{l}\text { 2. Safety and Rule of Law } \\
\text { (Personal Safety; National } \\
\text { Security; Accountability; Rule } \\
\text { of Law) }\end{array}$ & $44^{\text {th }}(42.8 \%)$ & $48.8 \%$ \\
\hline $\begin{array}{l}\text { 3. Participation and Human } \\
\text { Rights (Participation; Rights; } \\
\text { Gender) }\end{array}$ & $26^{\text {th }}(53.1 \%)$ & $47 \%$ \\
\hline $\begin{array}{ll}\text { 4. } & \text { Human } \\
& \text { Development(Education; } \\
\end{array}$ & $38^{\text {th }}(50.7 \%)$ & $45.7 \%$ \\
\hline
\end{tabular}


Health; Welfare)
OVERALL RANKING

$33^{\text {rd }}(47.9 \%)$

$43.2 \%$

Source: Author (based on information available on the website of Mo Ibrahim Foundation accessed on 29/06/2019).

Table 5. Nigeria's Ranking in Annual Prosperity Report, 2017

\begin{tabular}{|c|c|c|}
\hline \multicolumn{2}{|r|}{ Sub-Indices } & \multirow{2}{*}{$\begin{array}{c}\text { 2017 Ranking } \\
\text { (Total = 142) } \\
104^{\text {th }}\end{array}$} \\
\hline 1. & $\begin{array}{l}\text { Economy: macro-economic policies; economic } \\
\text { satisfaction and expectations; foundations for } \\
\text { growth; and financial sector efficiency. }\end{array}$ & \\
\hline 2. & $\begin{array}{l}\text { Entrepreneurship and Opportunity: } \\
\text { entrepreneurial environment; promotion of } \\
\text { innovative activity; and evenness of opportunity. }\end{array}$ & $107^{\text {th }}$ \\
\hline 3. & $\begin{array}{l}\text { Governance: effective and accountable } \\
\text { government; fair elections and political } \\
\text { participation; and rule of law. }\end{array}$ & $126^{\text {th }}$ \\
\hline 4. & $\begin{array}{l}\text { Education: access to education; quality of } \\
\text { education; and human capital. }\end{array}$ & $122^{\text {nd }}$ \\
\hline 5. & $\begin{array}{l}\text { Health: basic health outcomes; } \\
\text { infrastructure; and preventive care. }\end{array}$ & $130^{\text {th }}$ \\
\hline 6. & $\begin{array}{l}\text { Safety and Security: national security and } \\
\text { personal safety. }\end{array}$ & $134^{\text {th }}$ \\
\hline 7. & $\begin{array}{l}\text { Personal Freedom: individual freedom; and } \\
\text { encouraging social tolerance. }\end{array}$ & $121^{\mathrm{st}}$ \\
\hline 8. & $\begin{array}{l}\text { Social Capital: social cohesion and engagement; } \\
\text { and community and family networks. }\end{array}$ & $82^{\text {nd }}$ \\
\hline & ALL RANKING & $132^{\text {nd }}$ \\
\hline
\end{tabular}

Source: Author (based on information available on the website of Legatum Institute accessed on 29/06/2019).

Table 6. Nigeria's Score on the Corruption Perception Index (CPI) 1996 - 2017

\begin{tabular}{|l|c|c|c|}
\hline Year & CPI Score & Nigeria's CPI Ranking & Remarks \\
\hline 1996 & 0.69 & $54 / 54$ & Most corrupt \\
\hline 1997 & 1.78 & $52 / 52$ & Most corrupt \\
\hline 1998 & 1.9 & $81 / 85$ & $2^{\text {nd }}$ most corrupt \\
\hline 1999 & 1.6 & $98 / 99$ & $2^{\text {nd }}$ most corrupt \\
\hline 2000 & 1.2 & $90 / 90$ & $2^{\text {nd }}$ most corrupt \\
\hline 2001 & 1.0 & $90 / 91$ & $2^{\text {nd }}$ most corrupt \\
\hline 2002 & 1.6 & $101 / 102$ & $2^{\text {nd }}$ most corrupt \\
\hline 2003 & 1.4 & $132 / 133$ & $2^{\text {nd }}$ most corrupt \\
\hline 2004 & 1.6 & $144 / 146$ & $2^{\text {nd }}$ most corrupt \\
\hline 2005 & 1.9 & $152 / 159$ & $3^{\text {rd }}$ most corrupt \\
\hline 2006 & 2.0 & $142 / 163$ & $5^{\text {th }}$ most corrupt \\
\hline 2007 & 2.2 & $147 / 180$ & $9^{\text {th }}$ most corrupt \\
\hline
\end{tabular}




\begin{tabular}{|l|l|l|l|}
\hline 2008 & 2.7 & $121 / 180$ & $59^{\text {th }}$ most corrupt \\
\hline 2009 & 2.5 & $130 / 180$ & $50^{\text {th }}$ most corrupt \\
\hline 2010 & 2.4 & $134 / 178$ & $44^{\text {th }}$ most corrupt \\
\hline 2011 & $24 \%$ & $143 / 182$ & $39^{\text {th }}$ most corrupt \\
\hline 2012 & $27 \%$ & $139 / 174$ & $35^{\text {th }}$ most corrupt \\
\hline 2013 & $25 \%$ & $144 / 175$ & $31^{\text {st }}$ most corrupt \\
\hline 2014 & $27 \%$ & $136 / 174$ & $38^{\text {th }}$ most corrupt \\
\hline 2015 & $26 \%$ & $136 / 167$ & $31^{\text {st }}$ most corrupt \\
\hline 2016 & $28 \%$ & $136 / 176$ & $35^{\text {th }}$ most corrupt \\
\hline 2017 & $27 \%$ & $148 / 180$ & $35^{\text {th }}$ most corrupt \\
\hline
\end{tabular}

Source: Author (based on data from the website of Transparency International - accessed on 29/06/2019).

The evidences summarized in Tables $1-5$ show that achieving prosperity, a mutually-reinforcing element with human security and national security, is an enormous challenge for Nigeria: the country has been a low human development country for close to three decades from the 1990s. It has consistently ranked in the bottom tenth percentile in the API; and in the IIAG it scored below 50\% in nine of the ten years covered and has been in the bottom one-third of the SSA countries covered. It is not a mere coincidence that this period of high levels of poverty and threats to health security has also been characterized by upheavals and myriad of crises in Nigeria as in many parts of Africa. The lack of capacity to effectively address the issues of extreme poverty, health security threats and social exclusion as well as marginalization of majority of ordinary citizens imply underdevelopment. This reinforces other critical issues that threaten developmental processes and national security in Nigeria.

At the heart of Nigeria's lack luster performance in the summarized evidence is the element of ineffective governance. Successive administrations in the country have linked this to the evil of corruption. In Table 6 above, the Corruption Perception Index (CPI) of Transparency International (TI) indicates an international corroboration. Hardly is any aspect of public life free from the blight of corruption in today's Nigeria. This worsens living conditions as it not only erodes legitimacy of government and its institutions, but also leads to the illegal diversion of resources meant for development of infrastructure and provision of the good things of life.

Theoretically, this element of ineffective governance, is being linked to various analyses in which Nigeria has been classified as a "failed, fragile or rogue state" (Osaghae 2010:75-131; Simbine and Oladeji 2010:807-842; Yagboyaju 2016:1-33). For more than a decade since 2007 when the World Bank reiterated the long-standing classification of Nigeria along with over 50 countries like Sao Tome, Papua New Guinea, Djibouti and Uzbekistan, Africa's most populous country, Nigeria, has despite its huge human and material endowments been persistently been so classified. States in this category are those which lack the will and capacity to engage productively with their own citizens so as to "ensure security of life and property; safeguard human rights; provide basic institution and infrastructure for development; confront development challenges of administrative capacity, chronic 
humanitarian crises, persistent or endemic social tensions, violence, threats of institutional breakdown and civil war" (Simbine and Oladeji, p. 808). These are states that suffer from one governance crisis to another and largely on the precipice of total disintegration.

Closely linked to this is the problem of poor leadership, which has been identified as the greatest obstacle to good governance and national development in Nigeria and many parts of Africa (see Yagboyaju 2013:118-133; 2015:8-21). Hardly can any development goal be attained in the absence of directional leadership. The importance and connection of effective governance and directional leadership to productivity and overall development of both public and private organizations including state agencies is unmistakable. Typically, countries that have consistently ranked high in prosperity and human development indexes are also in top positions in rankings for the world's best governed countries, while it is the opposite in the cases of countries that rank as highly corrupt and poorly governed. This largely explains the foundational elements of the threats to human security and national security in Nigeria and many parts of Africa.

\section{Conclusion}

This study sought to analyze the interconnected concepts of human security, social justice and sustainable development in the African continent, with specific focus on Nigeria. For example, the model of human security forms part of a larger development process that highlights the obligation of governments to address issues of extreme poverty and health security as well as in protecting vital human freedoms. It reinforces existing development frameworks such as human rights based, and sustainable development approaches, by looking at the wide array of situations that threaten the survival, livelihood and dignity of people, especially the vulnerable.

This is situated in an analytic frame which draws strength from current debates on the resurgence of institutionalism and state fragility, and the mutually reinforcing effects of ineffective governance and poor leadership. In effect, the very essence of government security of lives and properties of citizens and residents, and its other important duties, including development goals and relationships with other countries, are hardly achieved in view of the weakness of the state and its institutions.

\section{Recommendations}

- From the content analyses of the various reports it did, this study isolated the lack of capacity by the state and its institutions to ensure compliance with regulations, provide effective governance and safeguard the rule of law as the most profound evidence of threats to human security and national security. In view of this, there is the urgent need for the restoration of institutional capacity.

- This can hardly be achieved in the absence of directional leadership. Therefore, civil society, especially the intelligentsia and other stakeholders must get more involved in public affairs so as to help in discovering directional leaders. It is preferable if this commences from community levels. 
- There are Ministries, Departments and Agencies (MDAs) of government saddled with specific responsibilities and duties in Nigeria, part of which are the issues of poverty and health security. However, the intervening variable of migration brought into the discussion on street begging is a clear indication of an overlap in the activities of agencies responsible for duties such as poverty reduction, health services, human movement and border security among others. In view of this, the importance of inter-agency collaboration cannot be overemphasized. Ultimately, the goal of government is the greatest happiness for the greatest number of citizens and, as such, all agencies of government must work together to actualize this goal.

- The date of commencement of the analyzed reports was mostly after the return of civil rule in the country. While it could be argued that the ongoing 20 years of democratization (1999-2019) should be sufficient for a major turnaround in institutional capacity and development goals attainment in the country, it is unmistakable that the probability of success is still higher under a democratic dispensation. In the light of this, democratization must be sustained in Nigeria with a view to strengthening values, principles and institutions associated with democratic rule.

\section{References}

Adamolekun, L. (2016). "The Idea of Nigeria: Two Challenges - Unity in Diversity and Prosperity”. Convocation Lecture, Lead City University, Ibadan, Nigeria, 09 November.

Ajakaiye, D. O., \& Olomola, A. S. (2003). "Overview of Poverty Reduction in Nigeria", in D.O. Ajakaiye and A.S. Olomola (Eds.) Poverty in Nigeria: A Multidisciplinary Perspective, Ibadan: NISER.

Akande, S. O., \& Roberts, F. (2010). "Nigeria: Profile of a Giant in the Sun", in S.O. Akande and A.J. Kumuyi (Eds.) Nigeria at 50 - Accomplishments, Challenges and Prospects, Ibadan: NISER.

Aning, K. (2016). "Negotiating the West African Conundrum: Developing Society through Human Security and Social Justice". Keynote Address at the conference: Africa since Independence: Promise, Pugnacity and Failure in the Post-Colonial Contexts, University of Ibadan, 03-05 August.

Bello, M. A., \& Roslan, A. H. (2010). Has Poverty reduced in Nigeria in 20 years after? European Journal of Social Sciences, 15(1), 7-17.

Erinosho, L. (2010). The Social Sector under a Democratic Dispensation, 1999-2007, in L. Olurode (Ed.) Reflections on a Decade of Democratization in Nigeria, Lagos: FriedrichEbert-Stiftung.

Falola, T. (2018). "Political Economy and the Culture of Underdevelopment", in T. Falola (Ed.) The Toyin Falola Reader on African Culture, Nationalism, Development and Epistemologies, Austin,, Texas: Pan African University Press.

Jega, A. M. (2010). "Nigeria's Foreign Policy and the Promotion of Peace, Development and Democracy", in A.M. Jega and J.W. Farris (Eds.)Nigeria at Fifty, contributions to Peace, 
Democracy and Development, Abuja: The Shehu Musa Yar'Adua Foundation.

Jost, J. T., \& Kay, A. C. (2010). Social Justice: History, Theory and Research, London: Wiley. https://doi.org/10.1002/9780470561119.socpsy002030

Kumuyi, A., \& Adesanya, A. (2010). "Future Prospects", in S.O. Akande and A.J. Kumuyi (Eds.) Nigeria at 50 -Accomplishments, Challenges and Prospects, Ibadan: NISER.

Lewis, P. M. (2011). Nigeria: Assessing Risks to Stability, Washington, DC: Center for Strategic and International Studies.

Miller, D. (1991). Recent Theories of Social Justice. British Journal of Political Science, 21(3), 371-391. https://doi.org/10.1017/S0007123400006207

National Bureau of Statistics (NBS). 2005. Poverty Profile for Nigeria, Abuja: NBS.

Olopoenia, R. (1998). A Political Economy of Corruption and Underdevelopment. Faculty of the Social Sciences Lecture Series, No. 10, University of Ibadan, Nigeria, 07 October.

Oluwa, K. (2012). Paradox of Growth without Development, The Punch (Lagos, Nigeria), 13 March, p. 16.

Osaghae, E. (2010). Revisiting the concepts of State Fragility and State Building in Africa, in S.O. Akinboye and M.M. Fadakinte (Eds.) Fifty Years of Nationhood? - State, Society and Politics in Nigeria (1960-2010), Lagos: Concept Publications Limited.

Paris, R. (2001). Human Security: Paradigm Shift or Hot Air? International Security, 26(2), 87-102. https://doi.org/10.1162/016228801753191141

Parkin, F. (1982). Social Closure and Class Formation, in A. Giddens and D Held (Eds.) Classes, Power and Conflict: Classical and Contemporary Debates, Berkeley: University of California Press. https://doi.org/10.1007/978-1-349-16801-9_9

Roberts, F. (1999). The Problem of Political Development in Nigeria, in Political Development in Nigeria: Analysis of Indicators, NISER Annual Monitoring Research, Ibadan: NISER.

Roberts, F., Benjamin, S. A., Simbine, A. T., Oladeji, A., \& Danjibo, N. D. (2008). Political Perspectives on Poverty in Nigeria, in O. Ajakaiye and A.S. Olomola (Eds.) Poverty in Nigeria: A Multi-Disciplinary Perspective, Ibadan: NISER.

Rogers, P., \& Hall, A. (2003). Effective Water Governance, Global Water Partnership. TEC Background Papers, No. 7.

Simbine, A. T. (2000). Citizen's Disposition towards Governance and Democratic Rule, NISER Monograph Series, No. 11, Ibadan: NISER.

Simbine, A. T., \& Oladeji, A. (2010). Overview, Challenges and Prospects of Governance and Political Development, in S.O. Akande and A.J. Kumuyi (Eds.) Nigeria at 50 Accomplishments, Challenges and Prospects, Ibadan: NISER. 


\section{Macrothink}

Journal of Public Administration and Governance

ISSN 2161-7104 2019, Vol. 9, No. 3

Taylor, V. (2013). "Social Justice: Reframing the "Social" in Critical Discourses in Africa", in S. Tangan (Ed.) African Perspective on Social Justice, Ghana: Friedrich-Ebert-Stiftung. https://doi.org/10.1093/oxfordhb/9780199760107.013.0020

The Punch. (2010). "Jumbo pay: Sanusi at Senate, refuses to apologise", (Lagos, Nigeria), 02 December, pp. 2 and 7.

UNDP. (2009). Human Development Report Nigeria 2008-2009: Achieving Growth with Equity, Abuja: UNDP.

United Nations. (2000). Millennium Summit Report, Copenhagen: UN.

Yagboyaju, D. A. (2013). Development Goals and the Leadership Question in Nigeria, Ibadan Journal of the Social Sciences, 11(2), 118-133.

Yagboyaju, D. A. (2015). Leadership Theory, Ibadan Journal of Peace and Development, 5 \&6, 8-21.

Yagboyaju, D. A. (2016). "Human Capital and Social Sector Development", in D.A. Yagboyaju (Ed.) Reflections on Politics, Governance and Economy in Contemporary Nigeria, Ibadan University Press.

Yagboyaju, D. A. (2017). Corruption, Democracy and Development: Lessons for Africa and Asia. African Journal of Sustainable Development, 7(2), 45-74.

\section{Online Materials}

www.drasatrust.org -Dr. Ameyo Stella Adadevoh (DRASA) Trust (accessed 21 June 2019 @ 17.54hrs).

www.njc.gov.ng/pressrelease - NJC thanks Buhari for accepting Onnoghen's voluntary resignation (accessed 17 June 2019 @ 17.16hrs).

www.premiumtimesng.com -How ex-NDDC director, accused of fraud, moved $\$ 1$ billion of public funds (accessed on 22 June 2019 @ 14.11hrs).

www.prosperity.com/rankings (or www.li.com) - The Legatum Prosperity Index (accessed 27 June2019 @07.22hrs).

www.punchng.com - EFCC invites NDDC MD, ED over alleged withdrawal of $¥ 2.8$ billion (accessed 22 June 2019 @ 14.09hrs).

www.saharareporters.com - EFCC detains former SGF Babachir Lawal (accessed on 22 June 2019 @ 14.15hrs).

www.sustainabledevelopment.un.org -Sustainable Development Goals (SDGs) UNDP (accessed no 18 June 2019 @ 17.32hrs). 


\section{Copyright Disclaimer}

Copyright for this article is retained by the author(s), with first publication rights granted to the journal.

This is an open-access article distributed under the terms and conditions of the Creative Commons Attribution license (http://creativecommons.org/licenses/by/4.0/). 